\title{
PLAUKŲ PRIEŽIŪROS PRIEMONIŲ NEPAGEIDAUJAMAS POVEIKIS: RAIŠKA, PASIRINKIMO KRITERIJAI
}

\author{
Gražina Šniepiené ${ }^{1}$, Vitalija Gerikiené $\dot{e}^{1,2}$ \\ ${ }^{1}$ Klaipédos valstybinè kolegija, ${ }^{2}$ Šiauliu valstybine kolegija
}

Raktažodžiai: plaukų priežiūros priemonès, pasirinkimo kriterijai, nepageidaujami poveikiai, išsilavinimas.

\begin{abstract}
Santrauka
Tyrimo tikslas - nustatyti moterų plaukų priežiūros priemonių pasirinkimo, patirtų nepageidaujamų poveikių ir išsilavinimo sąsajas. Atliktas kiekybinis tyrimas: anoniminé anketine apklausa. Tyrime dalyvavo 386 Klaipédos miesto moterys. Statistinè duomenu analizè atlikta, naudojant duomenų kaupimo ir analizès SPSS programos 17 versijos programini paketą. Tyrimo rezultatai atskleidè, kad didžioji respondentu dalis patyrè nepageidaujamų poveikių, susijusių su plaukų priežiūros priemonių vartojimu. Jiems renkantis plaukų priežiūros priemones siekiama estetinè išvaizda buvo mažiau svarbi. Respondentams, nepatyrusiems nepageidaujamų poveikių, buvo mažiau svarbi kaina, gaminio kvapas ir pagaminusios kompanijos vardas. Respondentai, ịgiję aukštesni išsilavinimą, mažiau patyrè nepageidaujamų poveikių, susijusių su plaukų priežiūros priemonių vartojimu. Renkantis priemones jiems buvo mažiau svarbi kaina ir ilgas priemonių galiojimo laikas. Žemesnio išsilavinimo respondentams buvo mažiau svarbi natūrali gaminių sudètis ir nekenksmingumas aplinkai.
\end{abstract}

\section{Ivadas}

Sveiki ir gražūs plaukai yra jaunystès simbolis, kartu ir priemone išreikšti savo individualumą ir stilių. Dabartinèje rinkoje yra labai daug plaukų priežiūros priemonių. Tačiau ne visos yra saugios, nes gali daryti neigiamą įtaką galvos odos ir plaukų būklei bei bendrai žmogaus sveikatai $[2,6$, $8,10,18]$. Tai dirgikliai, alergenai, endokrininès sistemos ardytojai, kitokio pobūdžio toksiškos medžiagos. [2, 6-8, $13,16,17]$. Kenksmingos medžiagos biokumuliuojasi aplinkoje, tokiu būdu netiesiogiai paveikdamos gamtą ir žmoniją [16]. Nors Europos šalyse kosmetikos priemonių sudètis yra reglamentuojama, tačiau nustatoma nesaugių kosmetikos gaminių. Juose randama cheminių medžiagų, kurių nėra nurodyta gaminio etiketeje [14]. Kai kurie jų ingredientai lètai skyla ir koncentruojasi žmogaus organizmo lipiduose, sukeldami sveikatos sutrikimus [7]. Be to, vartotojai gali įsigyti priemonių internetu iš įvairių pasaulio kraštų, kur griežta reglamentacija kosmetikos sudečiai netaikoma [13]. Kosmetikos gaminių poveikis, taip pat ir nepageidaujamų reakcijų pasireiškimas arba nepasireiškimas priklauso nuo kosmetinių priemonių pasirinkimo bei jų naudojimo ịpročių. Būtina skirti daugiau dėmesio šiu gaminių vartotojams dèl sveikatai palankių priemonių pasirinkimo, formuojant jų pirkimo ịpročius [17].

Tyrimo tikslas - nustatyti moterų plaukų priežiūros priemonių pasirinkimo, patirtų nepageidaujamų poveikių ir išsilavinimo sąsajas.

\section{Tyrimo medžiaga ir metodai}

Atliktas kiekybinis tyrimas: anoniminė anketinè apklausa. Tyrimas vykdytas 2016 m. Klaipedos mieste. Remiantis Klaipédos miesto savivaldybės visuomenès sveikatos stebėsenos 2015 m. ataskaita 2016 m. pradžioje Klaipédos mieste moterų buvo 84873 [15]. Pasirinkus 95 proc. reikšmingumo lygmenį ir paklaidos ribą \pm 5 proc. [7], mūsų tiriamos populiacijos dydis apsprendè minimalų imties dydị $(n=398)$. Apklausa vykdyta kirpyklose ir vaistinėse, kuriose prekiaujama plaukų priežiūros priemonèmis. Apklaustos 386 moterys.

Taikytas originalus, mokslo informacijos šaltiniais grịstas, klausimynas. Plaukų priežiūros gaminių pasirinkimo kriterijai suskirstyti ị išorinius (gaminio ịpakavimas, kvapas, galiojimo laikas, gamintojo žinomumas, draugų rekomendacija) ir vidinius (gaminio poveikis grožiui ir sveikatai, natūrali sudètis, gaminio nekenksmingumas aplinkai, išbandytas gaminys). Nustatytas pakankamas tiriamujų plaukų priežiūros pasirinkimo kriterijų klausimų vidinis skalès patikimumas: Kronbacho (Cronbach) alfa 0,659.

Klausimyne naudota 5 balų Likerto (Likert) skalè. Vertinant tiriamųu plaukų priežiūros pasirinkimo kriterijus išskirti atsakymų variantai: labai svarbu, svarbu, nei svarbu, nei nesvarbu, nesvarbu, visiškai nesvarbu. Analizuojant duomenis atsakymų variantai sublokuoti ir išskirtos trys 
atsakymų grupės: 1) svarbu (sujungiant atsakymų variantus: labai svarbu ir svarbu), 2) nei svarbu, nei nesvarbu, 3) nesvarbu (sujungiant atsakymų variantus: visiškai nesvarbu ir nesvarbu).

Tiriamųų patirtų nepageidaujamų poveikių, panaudojus plaukų priežiūros priemones, vertinimas skirstytas ị dvi grupes: 1) pasireiškè nepageidaujami poveikiai, 2) nepasireiškè nepageidaujami poveikiai. Siekiant išsiaiškinti, kokius nepageidaujamus poveikius patyre tiriamieji, buvo pateiktas klausimas, prašant pažymèti patirtus nepageidaujamus poveikius, panaudojus plaukų priežiūros priemones, kuriame buvo galimybė pasirinkti atsakymų variantus: alerginès reakcijos (berimai, kontaktinis dermatitas, alerginis rinitas, bronchinè astma), nemalonūs galvos odos reiškiniai (niežulys, pleiskanojimas).

Tiriamujų vertinimas pagal jų išsilavinimą skirstytas i penkias grupes: pradinis, pagrindinis, vidurinis, aukštesnysis, aukštasis. Tiriamieji pagal išsilavinimą pasiskirste taip: pagrindinio ( 3,2 proc., $\mathrm{n}=12$ ); vidurinio ( 36,3 proc., $\mathrm{n}=138$ ); aukštesniojo (21,6 proc., $\mathrm{n}=82)$; aukštojo ( 38,9 proc., $\mathrm{n}=148$ ) išsilavinimo respondentų.

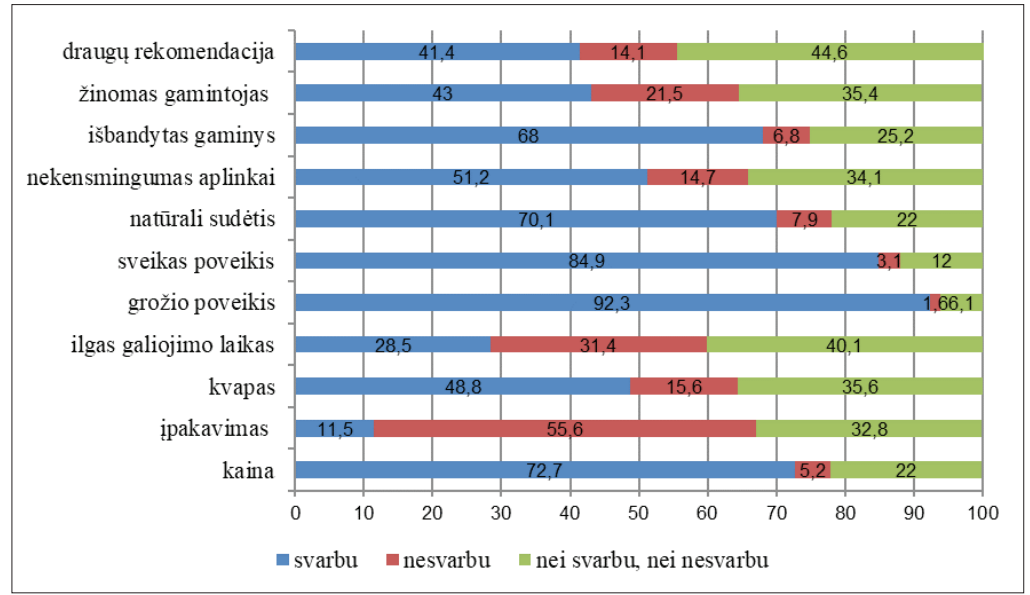

1 pav. Respondenčių plaukų priežiūros gaminių pasirinkimo kriterijai (proc.)

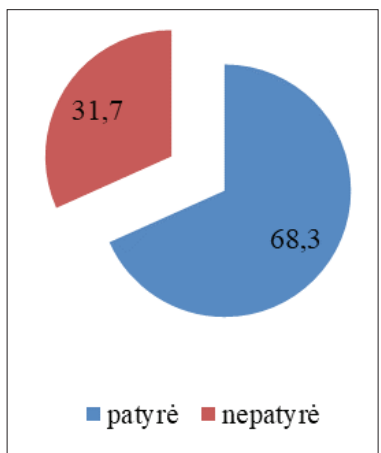

2 pav. Nepageidaujamus reiškinius, naudojant plaukų priežiūros gaminius, patyrusių ir nepatyrusių respondenčių pasiskirstymas (proc.)

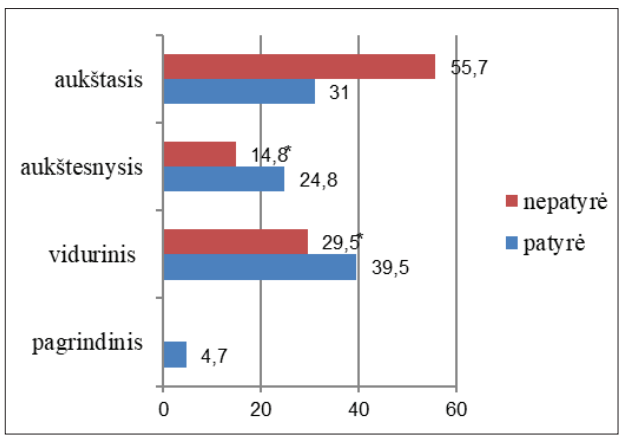

3 pav. Tiriamujų nepageidaujamų reiškinių patyrimas pagal jų išsilavinimą (proc.)

$\chi^{2}=24,85 ; l l s=3 ; p=0,000$

$\stackrel{*}{*}<0,05$ lyginant su aukštaji išsilavinima turinčiomis respondentemis

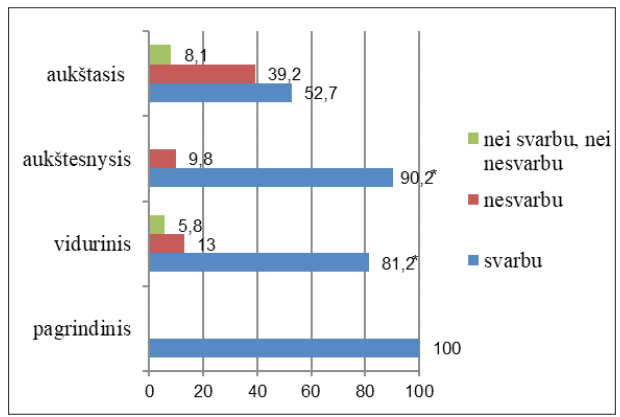

4 pav. Tiriamųų plaukų priežiūros gaminių pasirinkimo pagal kainos svarbą sąsajos su išsilavinimu (proc.)

$\chi^{2}=54,49 ;$ lls $=6 ; p=0,000$

$\hat{p}<0,05$ lyginant su aukštaji išsilavinima turinčiomis respondentemis 


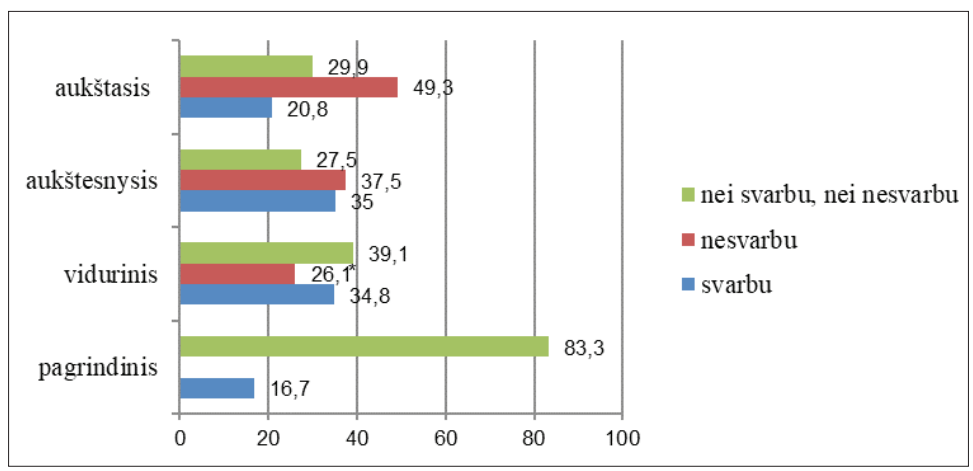

5 pav. Tiriamųjų plaukų priežiūros gaminių pasirinkimo pagal ilgą galiojimo laiką sąsajos su išsilavinimu (proc.)

$\chi^{2}=29,11 ; l l s=6 ; p=0,000$

${ }^{*}<0,05$ lyginant su aukštajį išsilavinima turinčiomis respondentèmis

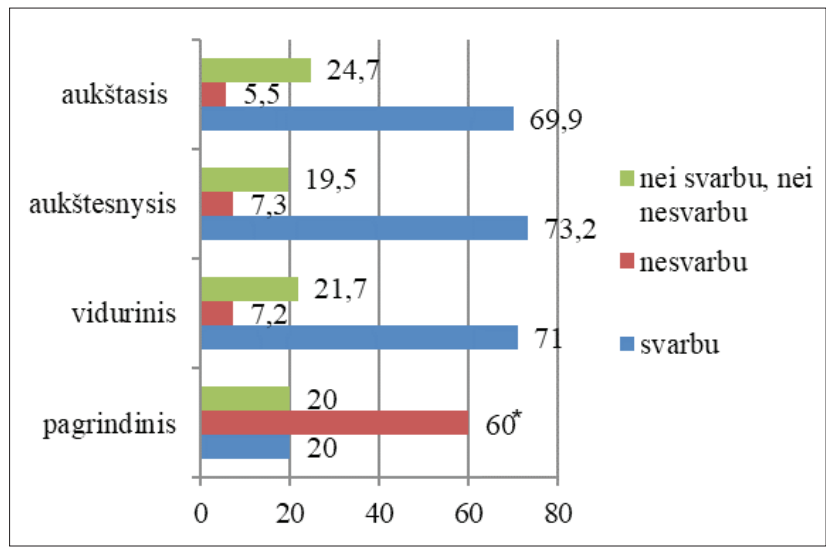

6 pav. Tiriamųjų plaukų priežiūros gaminių pasirinkimo pagal natūralią sudètį sąsajos su išsilavinimu (proc.)

$\chi^{2}=39,61 ; l l s=6 ; p=0,000$

${ }_{p}^{*}<0,05$ lyginant su aukštaji, aukštesniji, vidurinị išsilavinima turinčiomis respondentemis

yra svarbi prieinama kaina. Daugiau nei pusei respondenčių svarbu, kad pasirenkamas gaminys būtų išbandytas (68 proc., $(\mathrm{n}=348)$, kad jo sudètis būtų kuo natūralesnè $(70,1$ proc., $\mathrm{n}=267)$, pusei $(51,2$ proc., $\mathrm{n}=195)$ - pasirinkto produkto nekenksmingas poveikis aplinkai. Mažiau nei pusei respondenčių svarbi draugų rekomendacija (41,4 proc., $\mathrm{n}=156$ ), žinomas gamintojas ( 43 proc., $\mathrm{n}=164$ ), pasirenkamos priemonès kvapas $(48,8$ proc., $\mathrm{n}=185)$. Daugiau nei pusei respondenčių (55,6 proc., $\mathrm{n}=212)$ nèra svarbus pasirenkamos plaukų priežiūros priemonès ịpakavimas (1 pav.).

Vertinant respondenčių patirtų nepageidaujamų poveikių dažni, nustatyta, kad nepageidaujamus reiškinius, naudojant plaukų priežiūros gaminius, patyrè 68,3 proc. $(\mathrm{n}=263)$ respondentų, iš jų 7,8 proc. $(n=30)$ patyrè alergines reakcijas (kontaktinis dermatitas, alerginis rinitas, bronchinè astma)

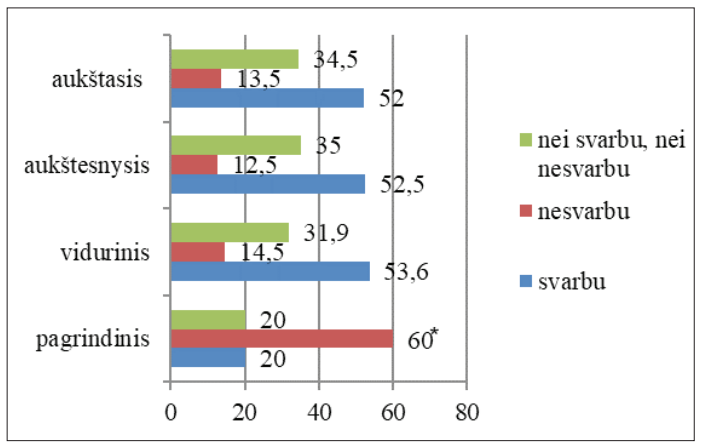

7 pav. Tiriamųjų plaukų priežiūros gaminių pasirinkimo pagal nekenksmingumą aplinkai sąsajos su išsilavinimu (proc.)

$\chi^{2}=16,96 ; l l s=6 ; p=0,009$

$w_{p}^{*}<0,05$ lyginant su aukštaji, aukštesniji, vidurini išsilavinima turinčiomis respondentemis

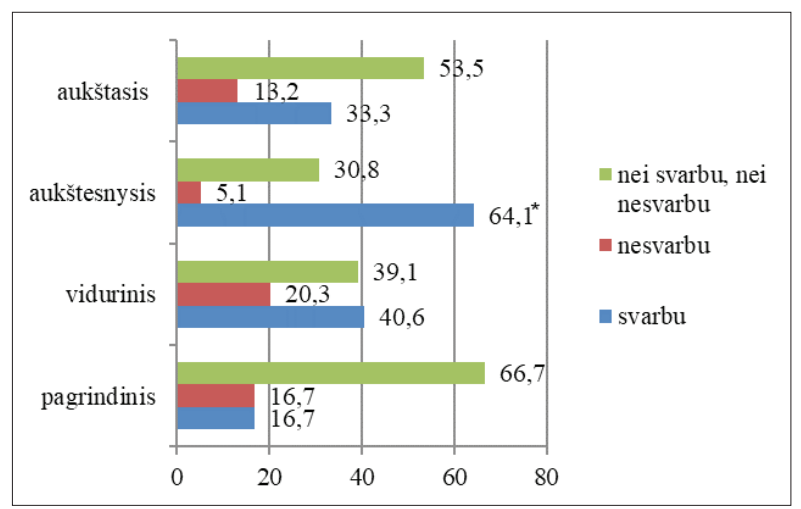

8 pav. Tiriamųjų plaukų priežiūros gaminių pasirinkimo pagal draugų rekomendacijas sąsajos su išsilavinimu (proc.) $\chi^{2}=30,04 ; l l s=6 ; p=0,000$

$\stackrel{\tilde{p}}{*}<0,05$ lyginant su aukštaji išsilavinima turinčiomis respondentèmis

ir 68,3 proc. $(\mathrm{n}=233)$ patyrè nemalonius galvos odos reiškinius: niežuli, pleiskanojimą. Nepatyrusių nepageidaujamų reiškinių, naudojant plaukų priežiūros gaminius, buvo 31,7 proc. $(\mathrm{n}=122)$ respondentu ( 2 pav.).

Vertinant respondenčių plaukų priežiūros gaminių išorinių pasirinkimo kriterijų sąsajas su nepageidaujamų reiškinių, naudojant plaukų priežiūros gaminius, patyrimu (1 lentelè), nustatytas statistiškai reikšmingas ryšys tarp nepatyrusių ir patyrusių nepageidaujamus poveikius renkantis plaukų priežiūros gaminius pagal kainą $(\mathrm{p}<0,01)$, pagal kvapą $(\mathrm{p}=0,000)$, pagal žinomą plaukų priežiūros priemonès gamintoją $(\mathrm{p}<0,05)$.

Respondentėms, nepatyrusioms nepageidaujamų reiškinių, naudojant plaukų priežiūros gaminius, nèra svarbi kaina, nèra svarbus gaminio kvapas ir pasirenkamos priemonès gamintojo ar kompanijos žinomumas (1 lentelè).

Vertinant respondenčių plaukų priežiūros gaminių vidinių 
1 lentelè. Respondenčių plaukų priežiūros gaminių pasirinkimo kriterijų sąsajos su nepageidaujamų reiškinių, naudojant plaukų priežiūros gaminius, patyrimu

${ }_{p}^{*}=0,02$ lyginant su patyrusiais nepageidaujamus poveikius

\begin{tabular}{|c|c|c|c|c|c|}
\hline \multirow{3}{*}{\multicolumn{2}{|c|}{$\begin{array}{l}\text { Plaukų priežiūros gaminių } \\
\text { išoriniai pasirinkimo kriterijai }\end{array}$}} & \multicolumn{4}{|c|}{$\begin{array}{c}\text { Nepageidaujamų reiškinių, } \\
\text { naudojant plaukų } \\
\text { priežiūros gaminius, } \\
\text { patyrimas }\end{array}$} \\
\hline & & \multicolumn{2}{|c|}{ Patyrè } & \multicolumn{2}{|c|}{ Nepatyrè } \\
\hline & & proc. & $\mathrm{n}$ & proc. & $\mathrm{n}$ \\
\hline \multirow{3}{*}{$\begin{array}{l}\text { Kaina } \\
\chi^{2}=8,59 ; 11 \mathrm{~s}=2 \\
\mathrm{p}=0,014\end{array}$} & svarbu & 73,4 & 193 & 72,1 & 88 \\
\hline & nesvarbu & 3,0 & 8 & 9,8 & 12 \\
\hline & $\begin{array}{l}\text { nei svarbu, nei } \\
\text { nesvarbu }\end{array}$ & 23,6 & 62 & 18,0 & 22 \\
\hline \multirow{3}{*}{$\begin{array}{l}\text { Ipakavimas } \\
\chi^{2}=3,68 ; 11 \mathrm{~s}=2 \\
\mathrm{p}=0,158\end{array}$} & svarbu & 14,4 & 38 & 8,2 & 10 \\
\hline & nesvarbu & 55,1 & 145 & 54,9 & 67 \\
\hline & $\begin{array}{l}\text { nei svarbu, nei } \\
\text { nesvarbu }\end{array}$ & 30,4 & 80 & 36,9 & 45 \\
\hline \multirow{3}{*}{$\begin{array}{l}\text { Kvapas } \\
\chi^{2}=35,29 ; 11 \mathrm{~s}=2 ; \\
\mathrm{p}=0,000\end{array}$} & svarbu & 52,5 & 138 & 43,4 & 53 \\
\hline & nesvarbu & 8,0 & 21 & $31,1^{*}$ & 38 \\
\hline & $\begin{array}{l}\text { nei svarbu, nei } \\
\text { nesvarbu }\end{array}$ & 39,5 & 104 & 25,4 & 31 \\
\hline \multirow{3}{*}{$\begin{array}{l}\text { Galiojimo } \\
\text { laikas } \\
\chi^{2}=3,05 ; 11 \mathrm{~s}=2 ; \\
\mathrm{p}=0,217\end{array}$} & svarbu & 26,3 & 68 & 33,3 & 40 \\
\hline & nesvarbu & 30,9 & 80 & 32,5 & 39 \\
\hline & $\begin{array}{l}\text { nei svarbu, nei } \\
\text { nesvarbu }\end{array}$ & 42,9 & 111 & 34,2 & 41 \\
\hline \multirow{3}{*}{$\begin{array}{l}\text { Žinomas } \\
\text { gamintojas } \\
\chi^{2}=7,35 ; 11 \mathrm{~s}=2 \\
\mathrm{p}=0,025\end{array}$} & svarbu & 45,2 & 118 & 38,3 & 46 \\
\hline & nesvarbu & 23,8 & 62 & 16,7 & 20 \\
\hline & $\begin{array}{l}\text { nei svarbu, nei } \\
\text { nesvarbu }\end{array}$ & 31,0 & 81 & 45,0 & 54 \\
\hline \multirow{3}{*}{$\begin{array}{l}\text { Draugu } \\
\text { rekomendacija } \\
\chi^{2}=0,020 ; 11 \mathrm{~s}=2 ; \\
\mathrm{p}=0,990\end{array}$} & svarbu & 41,6 & 106 & 41,0 & 50 \\
\hline & nesvarbu & 14,1 & 36 & 13,9 & 17 \\
\hline & $\begin{array}{l}\text { nei svarbu, nei } \\
\text { nesvarbu }\end{array}$ & 44,3 & 113 & 45,1 & 55 \\
\hline
\end{tabular}

pasirinkimo kriterijų sąsajas su nepageidaujamų reiškinių, naudojant plaukų priežiūros gaminius, patyrimu (2 lentelè), nustatytas statistiškai reikšmingas ryšys tarp nepatyrusių ir patyrusių nepageidaujamus poveikius renkantis plauku priežiūros gaminius pagal grožio poveikị $(\mathrm{p}=0,01)$, pagal sveiką poveikị $(\mathrm{p}<0,05)$, pagal nekenksmingumą aplinkai $(\mathrm{p}=0,001)$, pagal jau ne kartą išbandytą priemonę $(\mathrm{p}<0,05)$.

Respondenčių, patyrusių nepageidaujamų reiškinių, naudojant plaukų priežiūros gaminius, kurioms yra svarbus grožio poveikis buvo mažiau ( 89,6 proc.) nei nepatyrusių nepageidaujamų reiškinių, kurioms grožio poveikis yra svarbus ( 98,3 proc.).

Vertinant respondenčių, patyrusių ir nepatyrusių nepageidaujamą poveikị, panaudojus plaukų priežiūros priemones, sąsajas su jų išsilavinimu, nustatytas itin statistiškai reikšmingas $(\mathrm{p}=0,000)$ ryšys ( 3 pav.). Daugiau tiriamujjų su aukštuoju (55,7 proc., $\mathrm{n}=68)$ nei tiriamujjų su aukštesniuoju $(14,8$ proc., $n=18)$ išsilavinimu nebuvo patyrę nepageidau-
2 lentelè. Respondentų plaukų priežiūros gaminių pasirinkimo kriterijų sąsajos su nepageidaujamų reiškinių, naudojant plaukų priežiūros gaminius, patyrimu

${ }^{*} p=0,000$ lyginant su patyrusiais nepageidaujamus poveikius

\begin{tabular}{|c|c|c|c|c|c|}
\hline \multirow{3}{*}{\multicolumn{2}{|c|}{$\begin{array}{l}\text { Plaukų priežiūros gaminių vidiniai } \\
\text { pasirinkimo kriterijai }\end{array}$}} & \multicolumn{4}{|c|}{$\begin{array}{l}\text { Nepageidaujamų reiškinių, } \\
\text { naudojant plaukų priežiū- } \\
\text { ros gaminius, patyrimas }\end{array}$} \\
\hline & & \multicolumn{2}{|c|}{\begin{tabular}{|l|} 
Patyrè \\
\end{tabular}} & \multicolumn{2}{|c|}{ Nepatyrè } \\
\hline & & proc. & $\mathrm{n}$ & proc. & $\mathrm{n}$ \\
\hline \multirow{3}{*}{$\begin{array}{l}\text { Estetinis poveikis } \\
\chi^{2}=8,87 ; 11 \mathrm{~s}=2 \\
\mathrm{p}=0,012\end{array}$} & svarbu & 89,6 & 232 & $98,3^{*}$ & 116 \\
\hline & nesvarbu & 2,3 & 6 & - & - \\
\hline & $\begin{array}{l}\text { nei svarbu, nei } \\
\text { nesvarbu }\end{array}$ & 8,1 & 21 & 1,7 & 2 \\
\hline \multirow{3}{*}{$\begin{array}{l}\text { Sveikatai palankus } \\
\text { poveikis } \\
\chi^{2}=7,19 ; 11 \mathrm{~s}=2 ; \\
\mathrm{p}=0,027\end{array}$} & svarbu & 86,3 & 227 & 81,7 & 98 \\
\hline & nesvarbu & 1,5 & 4 & 6,7 & 8 \\
\hline & $\begin{array}{l}\text { nei svarbu, nei } \\
\text { nesvarbu }\end{array}$ & 12,2 & 32 & 11,7 & 14 \\
\hline \multirow{3}{*}{$\begin{array}{l}\text { Natūrali sudètis } \\
\chi^{2}=3,21 ; 11 \mathrm{~s}=2 \\
\mathrm{p}=0,201\end{array}$} & svarbu & 71,4 & 185 & 67,2 & 82 \\
\hline & nesvarbu & 6,2 & 16 & 11,5 & 14 \\
\hline & $\begin{array}{l}\text { nei svarbu, nei } \\
\text { nesvarbu }\end{array}$ & 22,4 & 58 & 21,3 & 26 \\
\hline \multirow{3}{*}{$\begin{array}{l}\text { Nekenksmingumas } \\
\text { aplinkai } \\
\chi^{2}=14,29 ; 11 \mathrm{~s}=2 ; \\
\mathrm{p}=0,001\end{array}$} & svarbu & 54,8 & 142 & 43,4 & 53 \\
\hline & nesvarbu & 10,0 & 26 & 24,6 & 30 \\
\hline & $\begin{array}{l}\text { nei svarbu, nei } \\
\text { nesvarbu }\end{array}$ & 35,1 & 91 & 32,0 & 39 \\
\hline \multirow{3}{*}{$\begin{array}{l}\text { Išbandytas ga- } \\
\text { minys } \\
\chi^{2}=10,35 ; 11 \mathrm{~s}=2 ; \\
\mathrm{p}=0,006\end{array}$} & svarbu & 66,7 & 174 & 70,8 & 85 \\
\hline & nesvarbu & 4,6 & 12 & 11,7 & 14 \\
\hline & $\begin{array}{l}\text { nei svarbu, nei } \\
\text { nesvarbu }\end{array}$ & 28,7 & 75 & 17,5 & 21 \\
\hline
\end{tabular}

jamo poveikio, panaudojus plaukų priežiūros priemones $(\mathrm{p}=0,000)$. Daugiau tiriamujų su aukštuoju $(55,7$ proc., $\mathrm{n}=68)$ nei tiriamujų su viduriniu $(29,5$ proc., $n=36)$ išsilavinimu nebuvo patyrę nepageidaujamo poveikio, panaudojus plauku priežiūros priemones $(\mathrm{p}=0,01)$.

Respondentems, nepatyrusioms nepageidaujamų reiškinių, naudojant plaukų priežiūros gaminius, nèra svarbi kaina, nèra svarbus gaminio kvapas ir pasirenkamos priemonès gamintojo ar kompanijos žinomumas (1 lentelè).

Vertinant respondenčių plaukų priežiūros gaminių pasirinkimo pagal kainos svarbą sąsajas su jų išsilavinimu, nustatytas itin statistiškai reikšmingas $(\mathrm{p}=0,000)$ ryšys $(4$ pav.). Mažiau tiriamujų su aukštuoju (52,7 proc., $n=78)$ nei tiriamujų su aukštesniuoju (90,2 proc., $\mathrm{n}=74)$ ir su viduriniu ( 81,2 proc., $\mathrm{n}=112)$ išsilavinimu yra svarbi kaina renkantis plaukų priežiūros priemones $(\mathrm{p}=0,000)$.

Vertinant respondenčiu plaukų priežiūros gaminių pasirinkimo pagal ilgą galiojimo laiką sąsajas su jų išsilavinimu, nustatytas itin statistiškai reikšmingas $(\mathrm{p}=0,000)$ ryšys $(5$ pav.). Daugiau tiriamujjų su aukštuoju ( 49,7 proc., $n=71)$ nei tiriamujų su viduriniu (26,1 proc., $n=36)$ išsilavinimu nèra svarbus ilgas plaukų priežiūros priemonių galiojimo laikas $(\mathrm{p}=0,02)$. 
Vertinant respondenčiu plaukų priežiūros gaminių pasirinkimo pagal gaminio natūralią sudètį sąsajas su jų išsilavinimu, nustatytas itin statistiškai reikšmingas $(\mathrm{p}=0,000)$ ryšys (6 pav.). Daugiau tiriamujų su pagrindiniu ( 60 proc., $n=6$ ) nei tiriamujų su aukštuoju $(5,5$ proc., $n=8)$, su aukštesniuoju $(7,3$ proc., $n=6)$ ir su viduriniu $(7,2$ proc., $n=10)$ išsilavinimu nèra svarbi natūrali plaukų priežiūros priemonių sudètis $(\mathrm{p}=0,02)$.

Vertinant respondenčių plaukų priežiūros gaminių pasirinkimo pagal nekenksmingumą aplinkai sąsajas su jų išsilavinimu, nustatytas labai statistiškai reikšmingas $(\mathrm{p}=0,01)$ ryšys ( 7 pav.). Daugiau tiriamuju su pagrindiniu (60 proc., $\mathrm{n}=6)$ nei tiriamujų su aukštuoju $(13,5$ proc., $n=20)$, su aukštesniuoju (12,5 proc., $\mathrm{n}=10)$ ir su viduriniu ( 14,5 proc., $\mathrm{n}=20)$ išsilavinimu nẻra svarbus plaukų priežiūros priemonių nekenksmingumas aplinkai $(\mathrm{p}=0,02)$.

Vertinant respondenčių plaukų priežiūros gaminių pasirinkimo pagal draugų rekomendacijas sąsajas su jų išsilavinimu, nustatytas itin statistiškai reikšmingas $(\mathrm{p}=0,000)$ ryšys ( 8 pav.). Daugiau tiriamujų su aukštesniuoju $(64,1$ proc., $\mathrm{n}=50)$ nei tiriamujų su aukštuoju $(33,3$ proc., $\mathrm{n}=48)$ išsilavinimu yra svarbus plaukų priežiūros priemonių pasirinkimas atsižvelgiant ị draugų rekomendacijas $(p=0,000)$.

\section{Rezultatų aptarimas}

Tyrimo tarp klaipédiečių duomenys atskleidè, kad tarp plaukų priežiūros priemonių pasirinkimo kriterijų dominavo estetinis poveikis plaukams. Kitų autorių darbai rodo, kad tarp svarbiausių asmens priežiūros gaminių pasirinkimo kriterijų yra kaina, produkto sudètis, pakuote, reklamos įtaka ir skatinimo priemonès, vietinis gamintojo pripažinimas, suformuota nuomoné apie gamintoją ar konkretų gamini ir pardavėjo žinios apie gaminius $[2,3,12,15]$. Amerikietėms labai svarbi išvaizda, jų pagrindinis kosmetikos priemonių pasirinkimo kriterijus yra estetinis poveikis ir patogus vartojimas. Prancūzès dažniau nei amerikietės renkasi prestižinę kosmetiką, patikimas gamintojas joms itin svarbus [19]. Afrikietès, priešingai nei Vakarų šalių moterys, neturi daug patyrimo pasirenkant kosmetikos priemones. Netgi išsilavinusios moterys nèra linkusios konsultuotis dèl kosmetikos poveikio su sveikatos priežiūros specialistais ar domètis interneto svetainèse. Pagrindinis veiksnys, lemiantis jų pasirinkimą, yra draugų rekomendacijos [11]. Perkančiųjų plaukų priežiūros priemones internetu svarbiausi pasirinkimo kriterijai: gamintojo vardas, natūrali gaminio sudètis, prieinama kaina bei vartotojų atsiliepimai. Pasirinkimo kriterijai tarp vyrų ir moterų skiriasi. Vyrams yra svarbesnis gamintojo vardas, o moterims - natūralesnè produkto sudètis ir prieinama kaina [12]. Tyrimai rodo, kad kvapas nèra pats svarbiausias plaukų priežiūros ir kitų kosmetikos priemonių pasirinkimo kriterijus [15]. Tačiau daugeliui vartotojų, tiek vyrams, tiek moterims, kvapas turi reikšmės renkantis kosmetiką [12].

Tyrimas tarp klaipėdiečiu parodè, kad tarp plaukų priežiūros priemonių pasirinkimo kriterijų ịpakavimas nebuvo svarbus. Tačiau rinkodaros specialistų tyrimai rodo, kad kosmetikos vartotojai dažnai renkasi pagal pakuotès, o ne pagal gaminio charakteristikas. Ipakavimas atlieka didelị vaidmenị pritraukiant pirkejjo dèmesị ir apibūdinant produktą. Pastaraisiais metais vartotojams tapo aktuali aplinkos apsauga, todèl jie renkasi pakuotes, kurios yra perdirbamos ar biologiškai skaidomos [5]. Pastaruoju metu Lietuvoje daug kalbama apie kosmetikos priemonių sudètị, diskutuojama apie jų nepalankų vartotojų sveikatai poveikį. Todėl nestebina, kad dalis respondenčių renkasi gaminius, atsižvelgdamos ị jų sudètị. Patyrusios nepageidaujamų poveikių, kosmetiką renkasi atidžiau, grožio kriterijus jiems mažiau svarbus. Daugelis respandenčių klaipėdiečių nurodo, kad vartojant plaukų priežiūros priemones patyrè galvos odos niežuli, pleiskanojimą, dalis respondenčių nurodo alergines reakcijas. Olandijoje atlikto tyrimo metu fiksuojant patirtus šalutinius kosmetikos priemonių poveikius, nustatyta, kad dažniausiai pasitaikę šalutiniai poveikiai - odos paraudimas, niežulys, deginimo jausmas [18]. Sintetiniai surfaktantai, esantys šampūnuose, gali išprovuokuoti galvos odos pažeidimus, pleiskanojimą, sausumą, eritemą, patinimą. Jie ardo apsauginị odos sluoksni, silpnina plaukų svogūnèlius [2]. Detergentams su natrio laurilsulfatu patenkant ant akių ar nosies gleivinès nustatyta sąsajų su véžinèmis ligomis [10]. Plaukų dažai sukelia ịvairių nepageidaujamų poveikių, dažniausiai alerginị kontaktinị dermatitą, galvos skausmą, niežulị. Alergines reakcijas dažnai sukelia sudetinè plaukų dažų medžiaga p-fenilendiaminas $[6,17]$. Nustatyta, kad ši medžiaga didina onkologinių ligų riziką $[6,10]$. Prie nepalankių sveikatai produktų taip pat priskiriamos plaukų tiesinimo priemones, kurių sudètyje yra aukštos formaldehido koncentracijos [13].

Daugelis respandentų klaipėdiečių nurodo, kad jiems buvo pasireiškę įvairių nepageidaujamų poveikių, susijusių su plaukų priežiūros priemonių naudojimu.Tačiau nepageidaujamas poveikis yra toks poveikis, kuomet sveikas žmogus, naudodamas kosmetikos gaminị pagal paskirti normaliomis sąlygomis, ima jausti nepageidaujamas reakcijas. Bet prie nepageidaujamo poveikio nepriskiriami tie reiškiniai, kurie atsiranda dèl netinkamo kosmetikos priemonès naudojimo. Šio tyrimo ribotumas: negalima atsakingai teigti, ar gaminiai buvo vartoti kaip nurodyta instrukcijoje, taip pat nebuvo nustatyta, ar nepageidaujamas poveikis tikrai buvo sukeltas kosmetikos priemonès, ar atsirado dèl kitų priežasčių.

Vartotojų išsilavinimas ir kosmetikos priemonių pasirinkimo kriterijai, kaip rodo tyrimai, turi glaudžių sąsajų. Aukš- 
tesnio išsilavinimo ir daugiau uždirbantys žmonės daugiau vartoja asmens priežiūros priemonių, negu žemesnio išsilavinimo ir mažiau uždirbantys [17]. Renkantis kosmetiką, gaminio kaina nèra svarbiausia, tačiau žmonių išsilavinimo lygis ir lytis turi lemiamą reikšmę. Tyrimai Malaizijoje rodo, kad palankių sveikatai produktų, neturinčių neigiamo poveikio aplinkai gaminių pirkimo priežastiniai veiksniai yra didesni tarp aukštesnio išsilavinimo asmenų, ypač tarp moterų [1]. Kai kurie tyrimai rodo, kad šalutinius kosmetikos priemonių poveikius dažniausiai patiria moterys, kadangi jos dažniau ir daugiau jų naudoja $[3,10]$. Tačiau, pasirenkant gaminius, moterims yra svarbesnis palankus sveikatai kriterijus, jos dažniau perka ekologišką kosmetiką, be to joms mažesnę ịtaką nei vyrams daro reklama [12, 18].

\section{Išvados}

1. Didžioji dalis respondenčių patyrè nepageidaujamų poveikių, susijusių su plaukų priežiūros priemonių vartojimu. Tarp respondenčių, patyrusių nepageidaujamų poveikių renkantis plaukų priežiūros priemones, siekiama estetiné išvaizda buvo mažiau svarbi. Respondentems, nepatyrusioms nepageidaujamų poveikių, tarp priemonių pasirinkimo kriterijų buvo mažiau svarbi kaina, gaminio kvapas ir pagaminusios kompanijos vardas.

2. Respondentès, ịijusios aukštesnị išsilavinimą, mažiau patyrè nepageidaujamų poveikių, susijusių su plaukų priežiūros priemonių vartojimu. Renkantis priemones joms buvo mažiau svarbi kaina ir ilgas priemonių galiojimo laikas. Žemesnio išsilavinimo respondentėms buvo mažiau svarbi natūrali gaminių sudètis ir nekenksmingumas aplinkai.

\section{Literatūra}

1. Chekima B, Wafa SA, Aisat Igau O, Chekima S, Sondoh SL. Examining green consumerism motivational drivers: does premium price and demographics matter to green purchasing? Journal of Cleaner Production 2016; 112 (4)20: 3436-3450.

2. Deguchi H, Aoyama R, Takahashi H, Isobe Y, Tsutsumi Y. Harmful effects of synthetic surface-active detergents against atopic dermatitis. Case Reports in Dermatological Medicine 2015; 5. Article ID 898262.

3. Ficheux AS, Wesolek N, Chevillotte G, Roudot AC, Consumption of cosmetic products by the French population. First part: Frequency data. Food and Chemical Toxicology 2015; 78: $159-169$

https://doi.org/10.1016/j.fct.2015.01.016

4. Folz D. Survey research for public administration. Thousand Oaks, CA: SAGE; 1996.

https://doi.org/10.4135/9781483327570

5. Grundey D. Functionality of product packaging: surveying consumers' attitude towards selected cosmetic brands. Economics \& Sociology 2010; 3 (1): 87-103.
https://doi.org/10.14254/2071-789X.2010/3-1/9

6. Gupta M. Hair dye induced erythema multiforme like allergic contact dermatitis. Our Dermatol Online 2017; 8(2): 177-178. https://doi.org/10.7241/ourd.20172.47

7. Haraux E, Braun K, Ricard J, Buisson P. et all. Maternal exposure to domestic hair cosmetics and occupational endocrine disruptors is associated with a higher risk of hypospadias in the offspring. Int. J Environ. Res Rublic Health 2017; 14 (1): 27.

8. Kaličanin B, Velimirović DA. Study of the possible harmful effects of cosmetic beauty products on human health. Biol Trace Elem Res 2016; 170 (2): 476-84.

https://doi.org/10.1007/s12011-015-0477-2

9. Klaipėdos miesto savivaldybès visuomenès sveikatos stebėsenos 2015 m. ataskaita. Prieiga per internetą: <http://www.hi.lt/ uploads/pdf/padaliniai/savivaldybiu_ataskaitos $/ 2015 \% 20 \mathrm{~m}$./ Klaipedos\%20m\%202015.pdf> [žiūrèta 2017-12-01].

10. Konduracka E, Krzemieniecki K, Gajos G. Relationship between everyday use cosmetics and female breast cancer. Polskie archiwum medycyny wewnetrznej. 2014; 124(5).

https://doi.org/10.20452/pamw.2257

11. Korai B. Determinants of African women's brand sensitivity toward cosmetics. Journal of International Consumer Marketing 2017; 29 (4): 250-264.

https://doi.org/10.1080/08961530.2017.1311125

12. Liu WY, Lin CC, Lee YS, Deng DJ. On gender differences in consumer behavior for on line financial transaction of cosmetics. Mathematical and Computer Modelling 2013; 58: $238-253$.

https://doi.org/10.1016/j.mcm.2012.08.010

13. Lerberghe L, Baeck M. A case of acute contact dermatitis induced by formaldehyde in hair-straightening products. Contact Dermatitis 2014; 70: 376-388.

https://doi.org/10.1111/cod.12181

14. Malinauskiene L, Blaziene A, Chomiciene A, Isaksson M. Formaldehyde may be found in cosmetic products even when unlabelled. Open Med 2015; 10: 323-328. https://doi.org/10.1515/med-2015-0047

15. Milotic $\mathrm{D}$. The impact of fragrance on consumer choice. Journal of Consumer Behaviour 2003; 3 (2): 179-191. https://doi.org/10.1002/cb.131

16. Morgan M, Deoraj A, Felty Q, Roy D. Environmental estrogen-like endocrine disrupting chemicals and breast cancer. Molecular and Cellular Endocrinology 2017; 457: 89-102. https://doi.org/10.1016/j.mce.2016.10.003

17. Park J Y, Lee K, Hwang Y, Hee J., Kim J. H. Determining the exposure factors of personal and home care products for exposure assessment. Institute Food and Chemical Toxicology 2015; 77: 105-110.

https://doi.org/10.1016/j.fct.2015.01.002

18. Salvareda JDW, Bragt PJC, Wit-Bos L, Rustemeyer T, Jan P. 
et. al. Results of acosmetovigilance survey in The Netherlands. Contact Dermatitis 2013; 68: 139-148.

https://doi.org/10.1111/cod.12005

19. Weber JM, Capitant de Villebonne J. Differences in purchase behavior between France and the USA: the cosmetic industry. Journal of Fashion Marketing and Management: An International Journal 2002; 6 (4): 396-407.

https://doi.org/10.1108/13612020210448673

\section{HEALTH ADVERSE EFFECTS OF HAIR CARE: EXPRESSION, SELECTION CRITERIA, EDUCATION G.Šniepienė, V.Gerikienè}

Key words: hair cosmetics, selection criteria, health adverse effects, education.

Summary

The article deals with hair cosmetics selection criteria and health adverse effects experienced by the use of these products among women in the city of Klaipeda, Lithuania.

The purpose of the research is to investigate the correlation between the selection criteria of hair care cosmetics, health adverse effects and women's education.

A quantitative research (an anonymous questionnaire) was performed. 386 women from Klaipeda city participated in the study. Statistical data analysis was carried out using IBM SPSS software.

Outcomes of the research. The study showed that most common criterion for the choice of hair cosmetics was an aesthetic effect on hair. This was indicated by the majority of respondents. The second most important criterion was a positive effect on health. The reasonable price was the third significant criterion.
More than half of the respondents experienced health adverse effects after the use of hair cosmetics. Some of them experienced allergic reactions (contact dermatitis, allergic rhinitis, bronchial asthma) and most of them experienced unpleasant scalp symptoms: itching and scaling. About the third of respondents did not experience health adverse effects after the use of hair cosmetics.

A statistically significant correlation was established between experienced and inexperienced health adverse effects in selecting hair care products according to reasonable price $(\mathrm{p}<0.01)$, on the basis of smell $(\mathrm{p}=0.000)$, according to well-known hair care producer $(p<0.05)$, according to aesthetic effect $(p=0,01)$, on the basis of favourable impact on health $(\mathrm{p}<0.05)$, and harmless effect on the environment $(\mathrm{p}=0.001)$.

Conclusions. Most of the respondents experienced health adverse effects related to the use of hair cosmetics. For them the aesthetic appearance was less significant. For the respondents who did not experience adverse reactions, reasonable price, smell and the name of the producer were less important. Respondents who have a higher education were less likely to experience adverse health effects related to the use of hair cosmetics. When choosing hair cosmetic products, the reasonable price and long expire date were less important for them. The natural composition of products and harmless effect on the environment were less important for the respondents with lower education.

Correspondence to: grazina.sniepiene@gmail.com

Gauta 2018-04-25

\section{KVIEČIAME PRENUMERUOTI "SVEIKATOS MOKSLŲ" ŽURNALĄ 2018 METAIS!}

Žurnalas "Sveikatos mokslai" (Index Copernicus, EBSCO host (Academic Search Complete), Gale (Academic OneFile), ProQuest (Ulrich's, Summon), Australia (ERA) 2012 Journal List (ERA ID 34962) skirtas visų specialybių gydytojams, slaugytojams ir kitiems specialistams, spausdina mokslinius straipsnius lietuvių, anglų kalbomis. Reikalavimai straipsniams atitinka mokslo leidiniams keliamus reikalavimus. Žurnalas kioskuose neparduodamas. Žurnalą, kuris leidžiamas kartą per du mènesius, galima užsiprenumeruoti visuose Lietuvos pašto skyriuose, taip pat internetu: www.prenumeruok.It

Prenumeratos kaina nesikeičia: visiems metams - 34,75 EUR, šešiems mėnesiams - 17,37 EUR, keturiems mėnesiams - 11,58 EUR, dviem mėnesiams - 5,79 EUR. Prenumeratos kodas: 5348. Žurnalo autoriams straipsnių spausdinimas mokamas.

Redakcija 